\title{
توثيق المعتقدات والافكار الدينية في بلاد الرافدين هن خلال بعض المشاهد الفنية البارزة
}

أ.د. طالب منعمم حبيب الشمري/ كلية التر بية / جامعة واسط

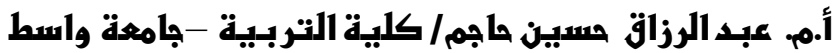

ان الحجم والكمية الهائلـة للمنجزات و الاثـار الفنية التي ابدع في تشكليها وعملهـا الفنـان و النحـات العر اقي القديم

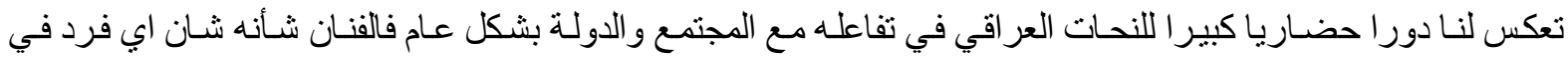
المجتمع يعيش في دو امـة الوشيجة الطبقيـة بين المجتمع ويتفاعل مـع الانعكاسـات و التـوترات الناجمة عنهـا ويتحدد عملـه

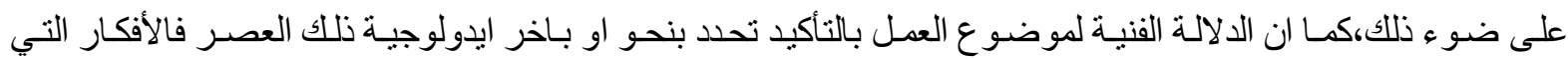
يعبر عنها في منظومة المشهح العـام مـاهي الا انعكاس لتوليفة المجتمع الذي يعبش بـه وبالتـالي يكون الفن بجميع عناصره

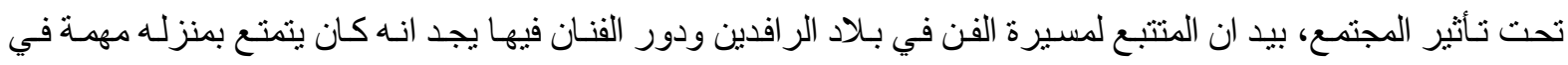
المجتمع اذ كان مقدرا من قبل افراد المجتمع.

: 1

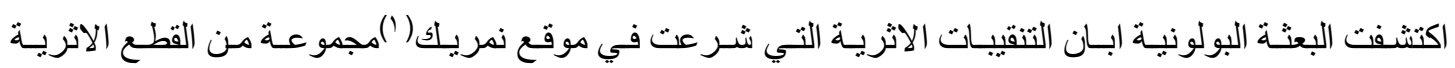

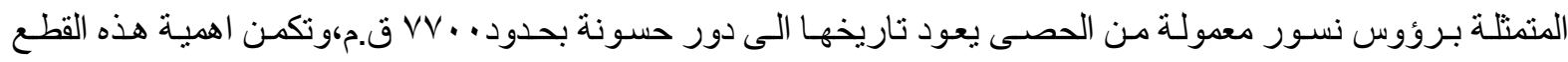
الاثرية كونها تمثل اولى الابداعات الفنية لما يعرف بالفنون التشكيلية لبلاد الر افدين تم الكثف عنها لحد الان. وتعد أقدم نحت مجسم في بلاد الر افدين هو عبارة عن رأس طير من الحجر عثر عليه في قريـة نمريك، يرجع

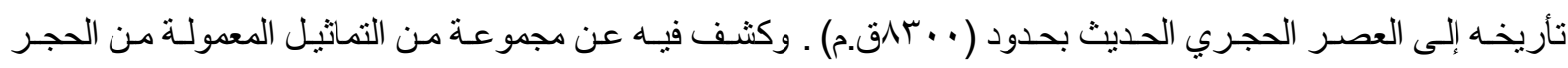

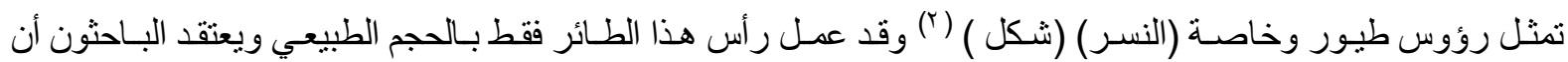

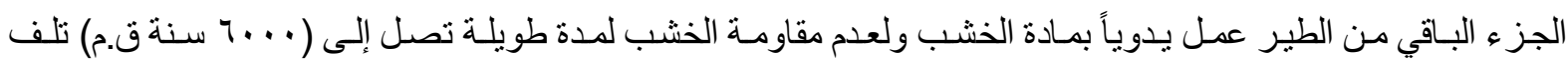

الخشب وبقي الرأس فقط المصنوع من حجر الرخام، أن هذه التماثيل صغيرة لا تزيد أطوالها عن · ل اسم(ب). يرى احد الباحثين بأن التصوير المـألوف لبعض الحيوانـات مثل النسر يشير إلى اعتقاد إنسـان العصر الحجري الحديث بـأن هنـاك تـدرج في الكون، السماء، والأرض، والعـالم السفلي، وقد يمـر الإنسـان عن هذا التـدرج من خـلال

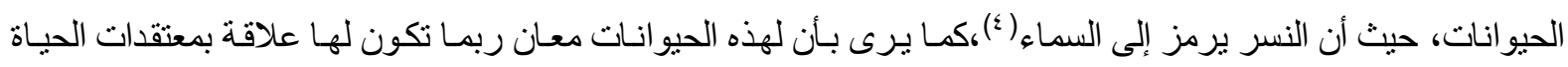

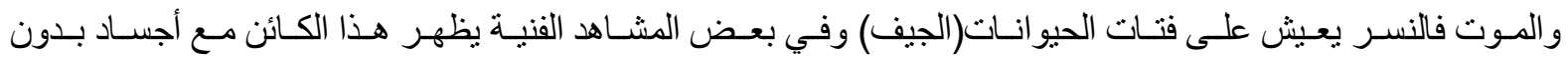

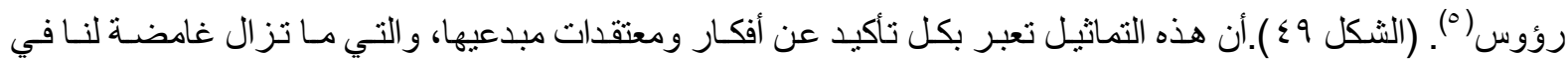
أغلب جو انبها، نظر اً لفقدان أيسة وثنائق كتابيـة من ذلك العصر تفسر لنـا مغزى هذه الإبداعات الفنبـة وان كل التحليلات

\section{الفنية لها لا يخرج عن سياق الاحتمالات(؟).}

تشكل هذه القطع الاثرية نوعا من التوثيق الذي يرتبط بنحو او بـاخر بالأفكار الدينية،اذ شكلت النواة الاولى في

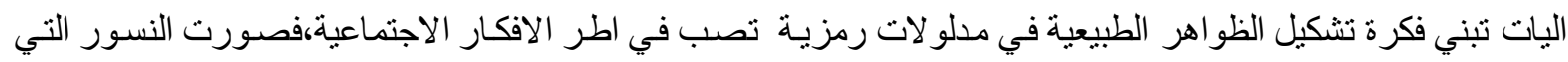

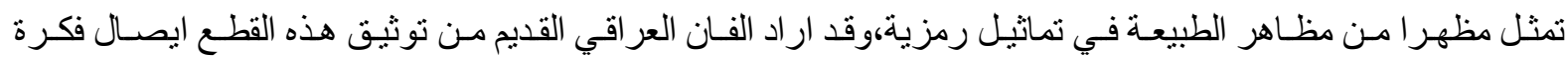

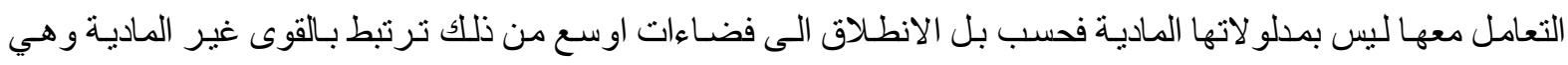
المسؤولة عما تشكله هذه الرموز سواء اكانت هذه القوى التي تمنلها النسور مرتبطة بمظـاهر القوة او لجب الحظوبط وبطلان 
لقد حاول الفنان العر اقي القيم في تصويره لهذه القطع ان يمزج بين و اقعية النسور وبين رمزيتها وان صغر حجم هذه الرؤوس ومكان وضعها يكون بحسبان الفنان قبل ان يشر ع في عمل هذه القطع وبالتـالي فان الصسورة الثـاملة لهذه القطع تدور في اطر فكرية الغاية منها تحقيق رغبات الفكر الاجتماعي في التعامل مع هذه القطع.

لقد وثقت هذه القطع اشكالا حيو انية طوطمية شكلت في حركاتها نوعا من الابـلاغ في عالم الفكر الذي سـاد

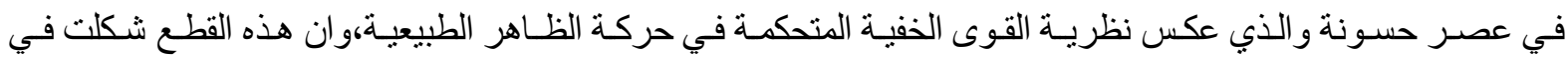
توثيقها نوعامن الافكار قد تتعلق بالتضر ع والرجاء او امرا او نهيا او غيرهـامن الافكار المرتبطة والمتحكمة بفضـاءات المعرفة الدينية وبذللك شكلت بهيئتها العامة نوعامن الخطاب اللغوي المرئي غير المحكي.

ورغم بسـاطة الادوات التي استخدمها النحسات في عمل هذه القطع من مـادة الحصى، الا انتـا نجده قد تعامل بكل حرفية معها اذ عادة مـا تكسر هذه الحصى اذا تعرضت الى ضربة ازميل خارجة عن الحسبان وبالتـالي فـان العمل الفني يتعرض الى التلف،لذا قد استعاض الفنـان بعملية نحته لهذه القطع بأسلوب الثحذ والدللك وان كان نلك قد استغرق منه وقتا طويلا الا انه وضع بالحسبان ماهية الحصى وقابليتها على التكسر وبالتالي فضل الاعتناء بعطله بدقة وبحرفية. . لقد مال الفنان في عمله لهذه القطع الفنية الى اسلوب التبسيط ولعل هذه الاسلوب نـاتج بسبب تعامله مـع الحصى التي يصعب معها عمل المفردات الدقيقة في القطعة الفنية او ان الفنان اراد من هذا التبسيط ان يعبر عن اسلوبه الفني من

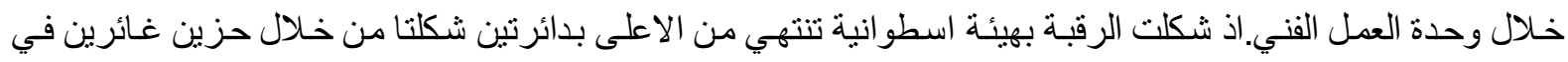

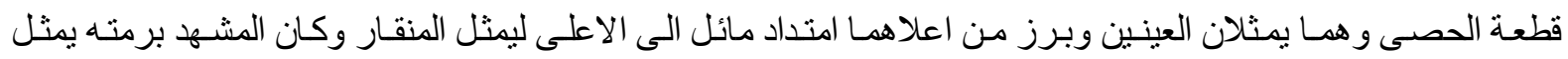
طائر النسر وهو ينظر الى السماء.

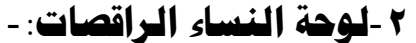

من المشـاهد المهـة التي ترتبط بتوثيق الافكار الدينية لبلاد الر افدين مـا يعرف لدى المختصين بلوحسة النسـاء

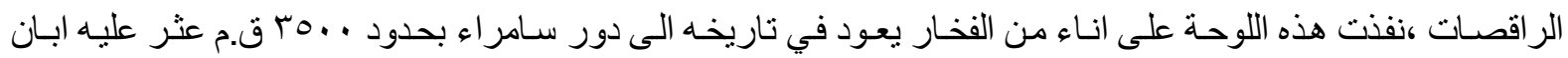

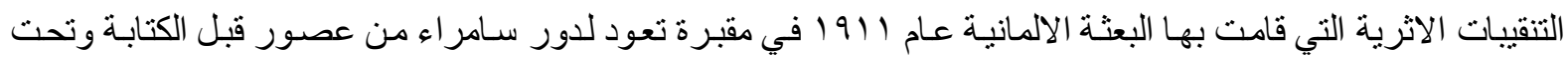

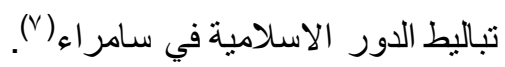

ظهرت على فخاريات سـامر اء(^). الملونـة والمحززة و الملونـة معاً نقوش زخرفية طبيعية تشتمل على الأشكال

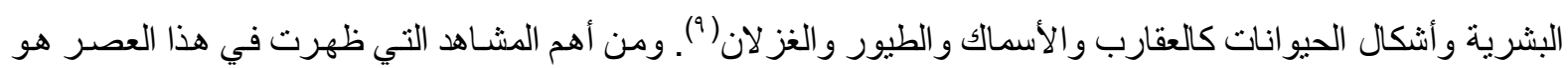
مشهر رسم الصليب المعقوف ،وقد قام الفنان بترتيب أشكالاً بشرية أو حيو انيـة أو هندسية بطريقة خاصـة نظهر من خـلال

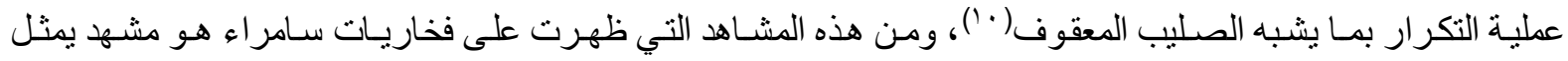

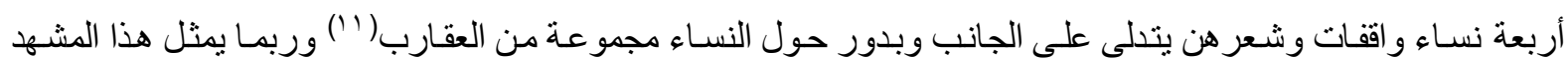

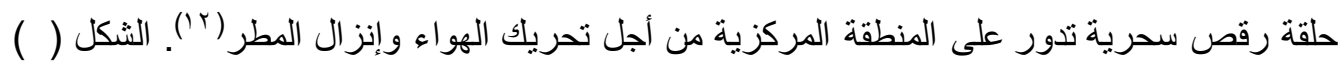
يعبر هذا المشهر عن الممارسات الجماعية التي تنبثق من خـال افكار وهواجس ترتبط ارتباطـا مباشـر ا بمظـاهر

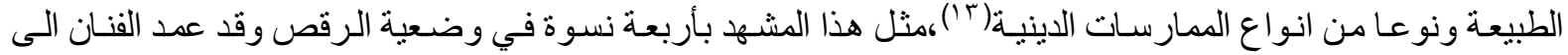
ترتيب النسوة بشكل متعامد بحيث ان الارجل تلتقي عند منتصف الانـاء بحيث قسمت قاعدة الانـاء الدائريـة الـى اربعـة اقسام متساوية،ويدور حول هذا النسوة مجموعة من اشكال العقارب بعكس اتجاه عقارب الساعة وعددها ثمانية عقارب. 
لقد نجح الفنان في عمله لهذا المشهد بان يزاوج مـا بين السطح الدائري المعد لتنفيذ المشهد عليه وما بين خاصية الحركة الدور انية للنسـاء بحيث يوحي للمتلقي التناسب مـا بين الموضوع وبين اداة العمل الفني،اذ عكست منظر ا تشكيليا

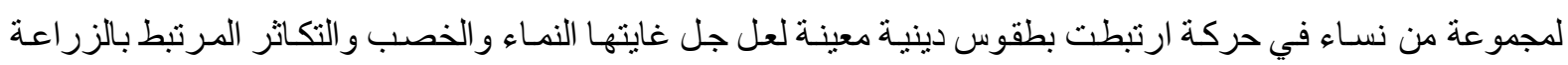
وديمومة البقاء(ء).

ان توثيق النسـاء الر اقصـات يعد مظهرا من مظـاهر الابـلاغ الفكري عن خصوصية مظـاهر تتعلق بالخصب

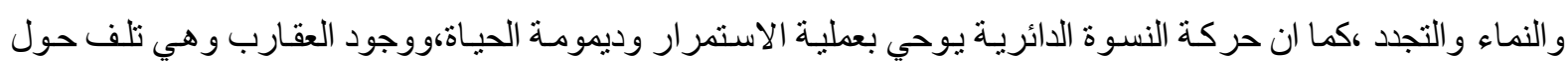

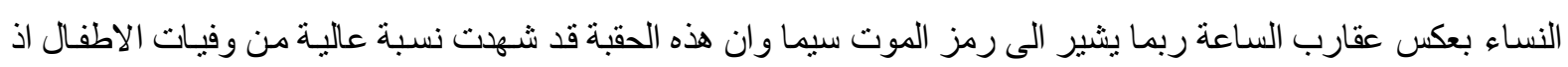

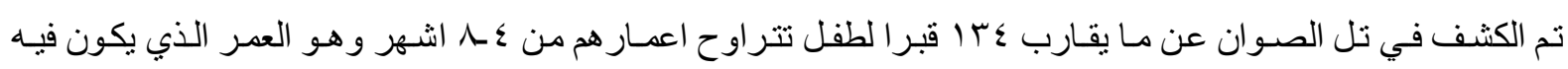

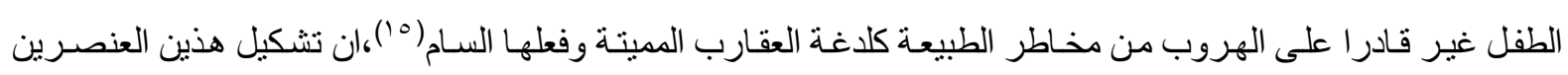

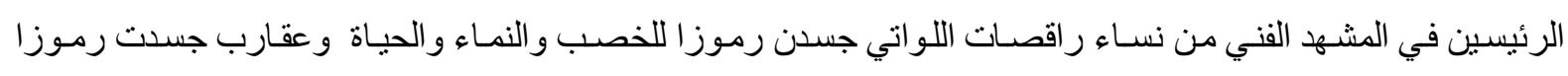
للموت و الفناء عكس نجاح الفنان العر اقي القديم في توثيقه لمفاهيم متعارضة في تشئ نشكيل فني واحد.

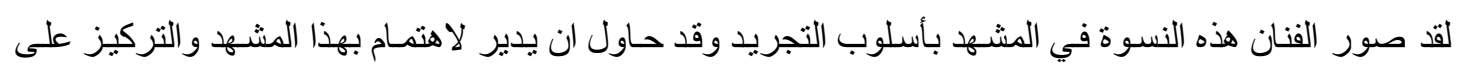

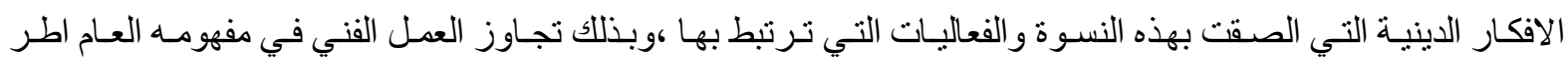

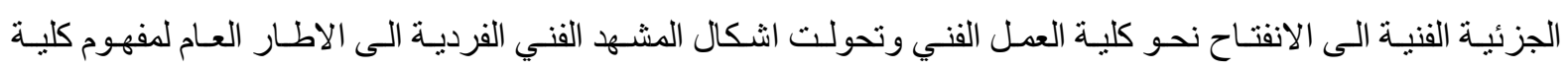

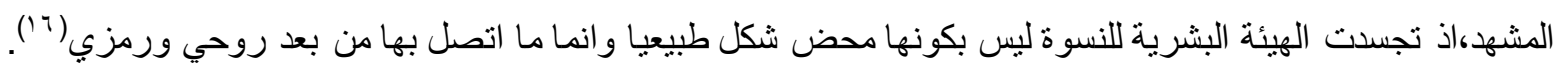

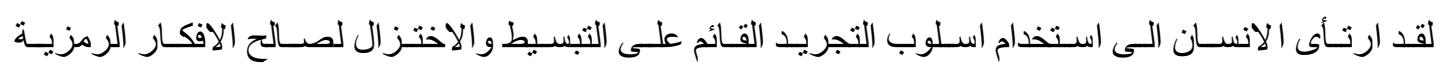

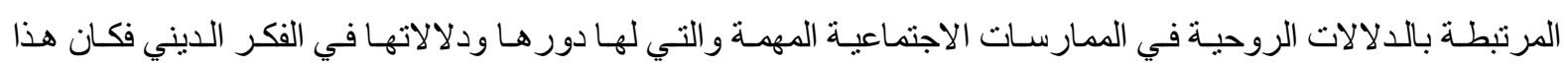

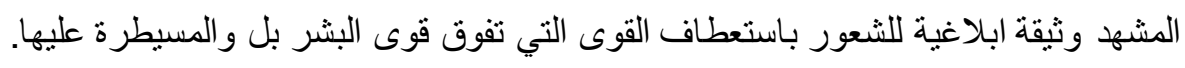
ان مثل هذه الموضـو عات قد شكلت بدور ها تفـاعلا قويـا بين العلاقـات الفكريـة والانظمـة الثـكلية.بيد ان الفنـان ار اد بتوثيقه لهذا المشهد من تحقيق حضور الافكار الدينية بوسائل بصرية ملموسة. ان اهمية توثيق هذه الافكـار الدينيـة المرتبطة بالمشهر الفني تكمن في تنشيط الخلجـات النفسية التي تتفاعل مـع

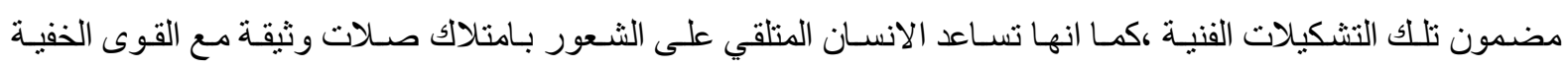

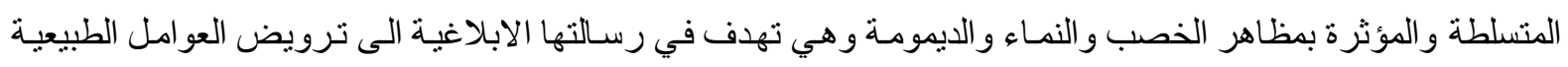

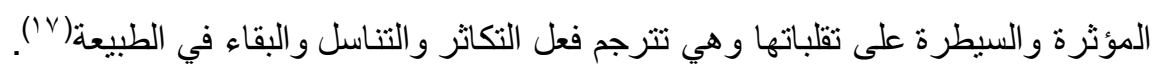

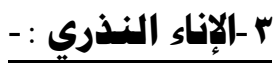

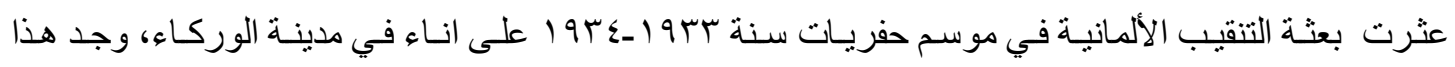
الأناء مكسوراً إلى خمس عشرة كسرة، وبعد رأب القطع و الصـاق بعضها ببعض في مختبر المتحف العر اقي اعيد ترميم

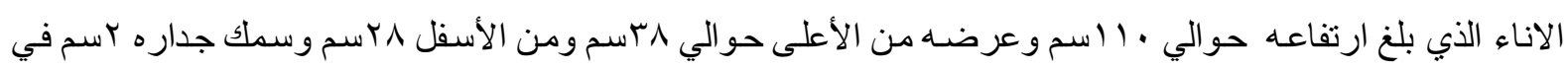
ألاعلى ويزداد ثخنا إلى أسفل(1^).

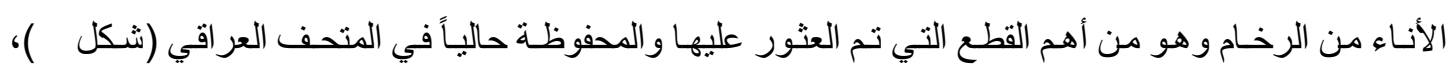

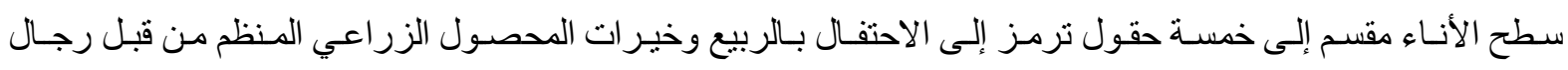


الدين(9). يمثل الحقل الأول موكبـاً فخمـاً يتقدم إلى حضـرة الإلهـة اينانسا وهي واقفة ووجههـا نحو اليسـار تتقبل النذور و الهايا و عليها ثوب يغطي كل جسمها عدا كتفها وذراعها الأيمن(·r).

ويحتمل أنها أيضاً تمثل الكاهنة الأولى في المعبد تتوب عن سيدتها الإلهة اينانا، وأن هذه الشخصية هي أبرز شخصية في تصاوير هذا الأناء بسبب حجمها الكبير الذي يشغل ارتفاع الحقل تمامـاً ولوققتها الني تدل على أنها تمثل هذا الموكب وتتقبل الهدايا، ووراء الإلهة رمزان عرفا في الكتاب الصسورية بأنهما يرمزان إلى الإلهة اينانا(الالهـة عشتار ) او سيدة السماء( (r))، وقد ذهب الباحث اندريـه الى ان هذه الرموز تمثل حزمة مـن القصب لتكون مسنداً في مدخل البنـاء المصنوع من القصب و البردي(rr).

ووراء الرمزين صورة لكبشين بحجم واحد واقفين الواحد بجانب الآخر تمامـاً، وقد رسم عليهما مصطبة ذات

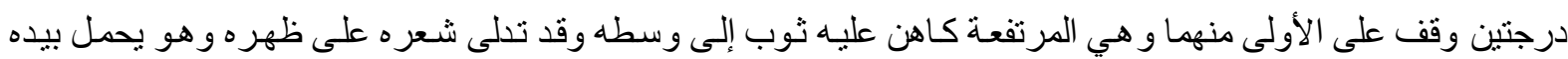

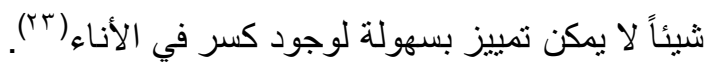

ووقف على المصطبة الثنانية وهي المنخفضـة كاهن أخر يشبه الأول بملابسه وشكله إلا أنه ممسك بيده اليمنى

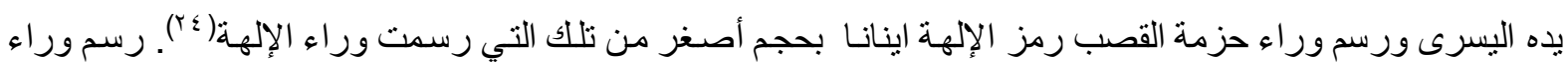

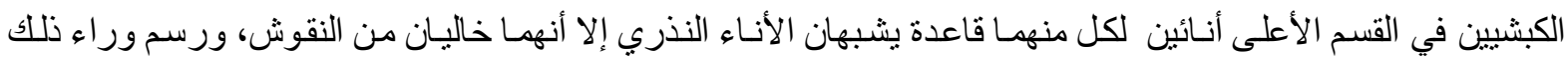
صور تان مصغرنان لحيو ان واسد، وأسفل هذين الإنـاءين طبقان قليل الانخفاض لهما قاعدتان وقد وضع فيهمـا مـا يشبه

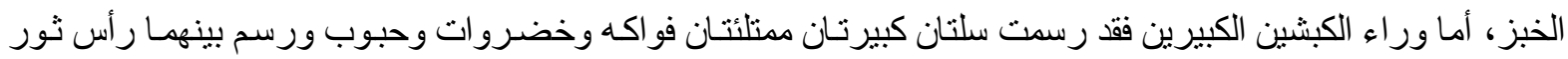

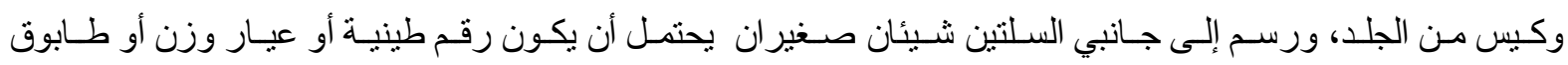
البناء(ro) (ro)

أمـا الحقل الثـاني نقتـت فيسه صـور تسعة خدمـة عـراة حالقي الرؤوس و اللحسى يحملون الهدايا والنذور المتمثلـة بسلال الفو اكه و الطعام، أمسا الحقل الثالث يحتوي على أصناف فلخرة من الماثية من أجل تقديمها كهدايا وقر ابين للإلهة

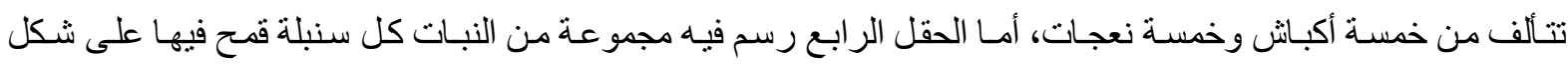
شجرة ذات سـاق طويلـة وتـاج مكون من ثلاثة أغصـان وهي أثشبه مـا تكون بالنظلة، وأسفل هذا الحقل خطـان متعرجـان

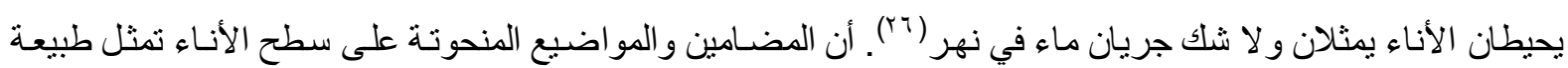

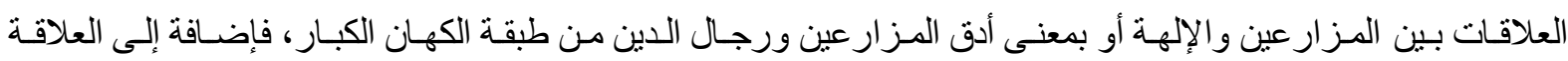
المادية بين الفلاح و الكاهن كانت هنالك علاقة روحية واضحة فالدين في العصر السومري كذللك الحـال بالنسبة للعصور

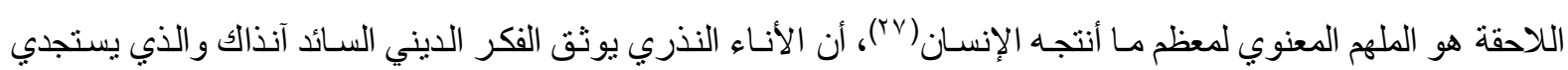
بشكل رئيسي مرضاة الإلهة سواء من قبل الملوك أو الناس العاديين. يمثل هذا الاناء اول خطابا فنيا دينيا لما يعرف لدى الباحثين بمظاهر الخصب والنماء، ان المتتبع لا فأريز هذا المشهح الفني يجد بوضوح العلاقة بينها وتنتقل عيناه من افريز الى اخر ليعبر كل افريز

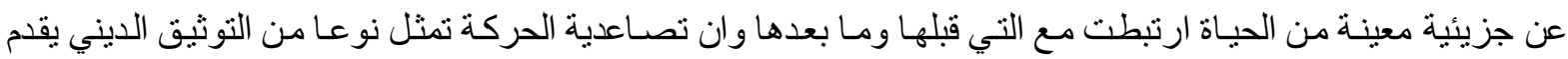

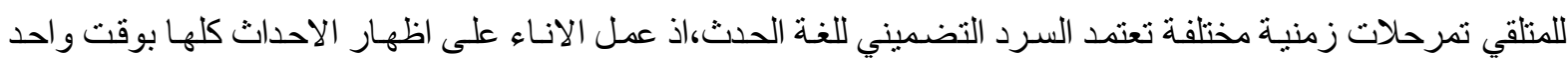

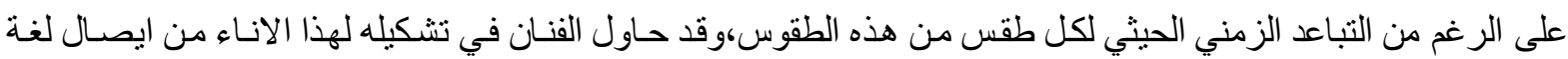


ذات توثيقا ابلاغيا للأفكار الدينية. فهو نموذج فني صغير لدورة الحياة والخصب(الماء،النبات ،الحيوان) التي تتحكم بها

ان الغرض من ذوثيق المشهد الفني على هذا الاناء يتمنل بهدف الفنان في تحقيق الابـلاغ الجماعي وتأكيد شـور

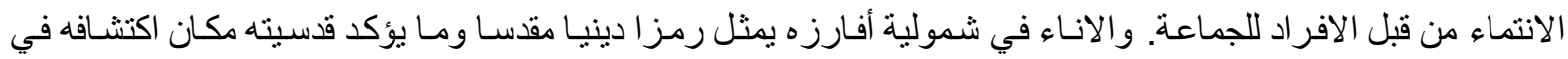
معبد الالهة اينانا،ضضلا عن ما يحمله من أفارز تتم على الجانب الديني للمشهد الفني.

اكتفى الفنـان بتمثيل موجـة المـاء بخطين متموجين فهي الصـورة الكامنـة في خزينـه الذهني عن فكرة المـاء،في

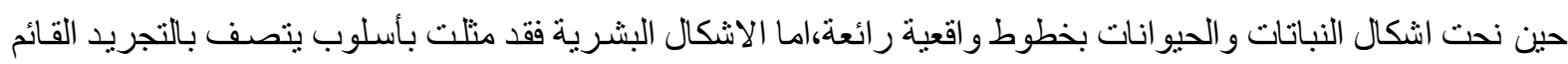
على نشاط الذهن في التبسيط والاختزال(ب^).

\section{ع -القيثارة الذهبية (الكنارة) :}

أظهرت التتقيبات في المقبرة الملكية في أور بقايـا من الألة الوتريـة الكنارة (Lyre) (99)، وآثار أخرى عليهـا

مشـاهد الآلـة نفسها، فقد عثر على رؤوس حيوانـات وقطع موزاييك و أثتار للخشب المعمولة منهـا هذه الآلات، ففي القبر

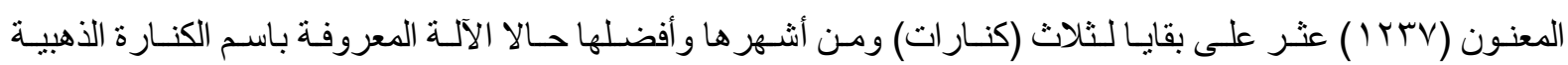

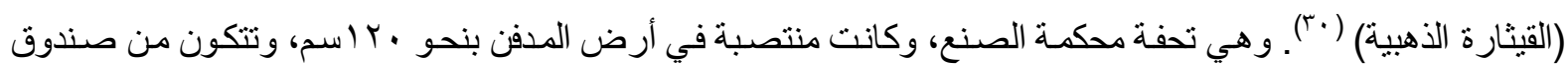

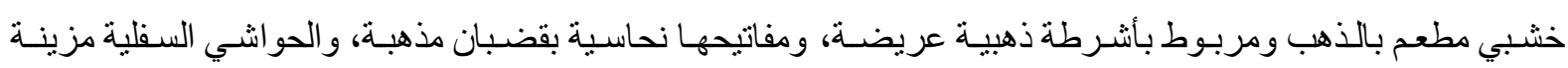

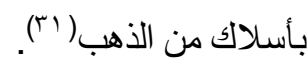

أمسا الصندوق الخشبي فأن شكله يقرب من شكل شبه منحرف في أعلى قسمه الأخير يوجد تقعر . وفي الحافـة

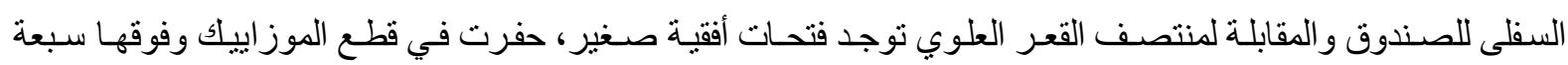

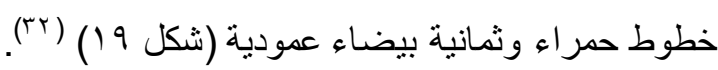
وخـلال هذه الفتحـات كانت تمـر الأوتـار التـي كانت قد ثبتـت في داخل الصندوق الصـوتي بواسطة عقدة أو

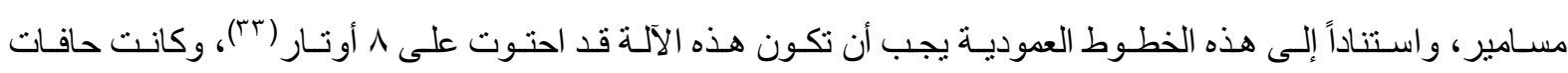
الصندوق الصوتي والساقان الجانبيتان مزدانة بزخرفة هندسية، معينات ومثلثات، من الصدف والحجر (عَّ). اختلفت الآراء في سبب اختبـار أو وضع رأس الثور على مقدمـة القيثنارة، فقد افترض عـالم الآثـار الموسبقية

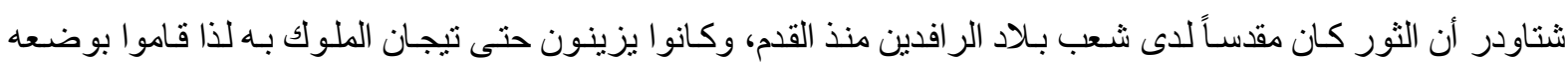

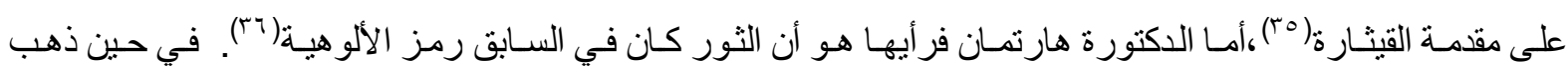

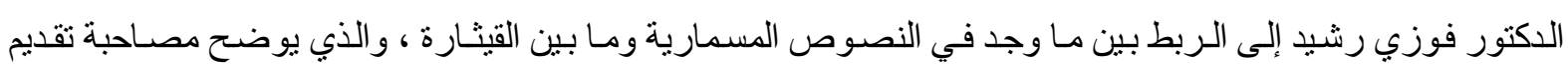

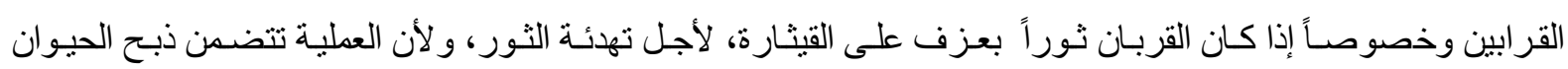

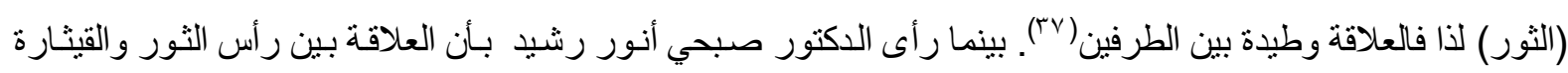

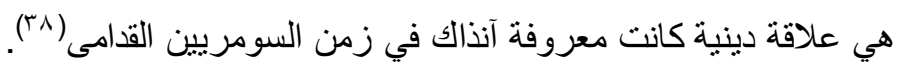
احتلت القبثارة مكانـة مهوسة في الفكر الديني في بـلاد الر افدين وقد استخدمت لأغر اض شتى وصساحبت هذه

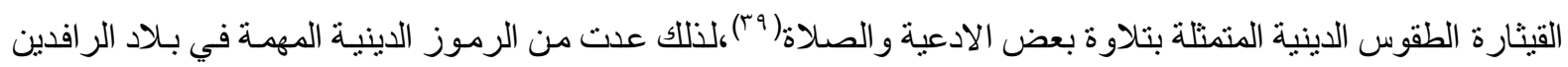


بيد ان هنـاك اشـار ات مسمارية تشـير الـى القسم بهذه القيثارة سو اء اكانت قيثارة تابعـة لمعبد الـه معين او حتى كـاهن

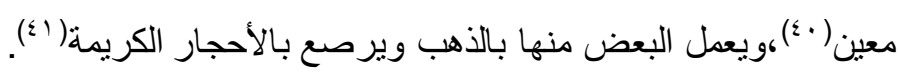

0 -ختم ايتانا :

تروي ملحمة ايتانا كيف أن الإلهة العظام شر عوا ببنـاء أول مدينة وهي مدينة كيش، واسكنوا فيها البشر وتولوا

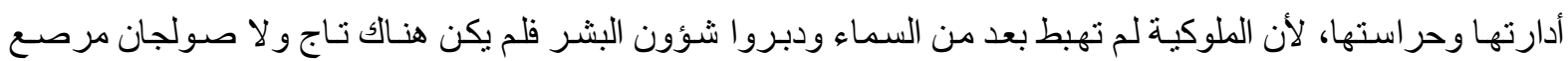
بأحجـار الـلازورد ولم تكن منصـة للعرش قد رفعت، وبدأ الإلهـة العظـام يبحثُون عن ملك شـاب لتثبيته ملكـاً على البلاد يوكلون إليه مهام الحكم و السلطان ليدير شؤون المدينة عوضـاً عنهم، فوجدوه في شخص صـالح يدعى اتيانـا وجرى تثنييته

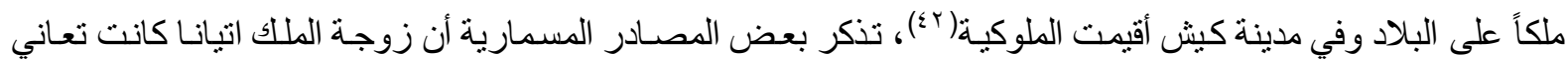
من العقم بسبب مرض ألم بها("َ).وكيف أن الملك اتيانا كان يسترحم الإله شمش ويصلي لـه ليزيل عنه العقم دعياً إيـاه أن

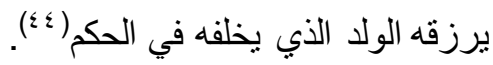

أن الحدث الأبرز في الملحمة هو صعود اتيانـا على ظهر النسر وطير انـه نحو السماء(0)، وكان هذا الطيران

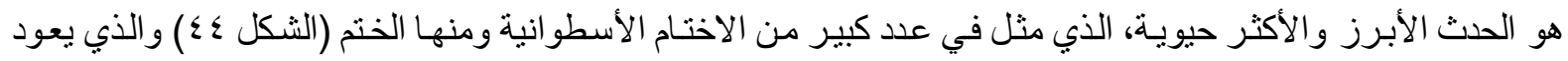

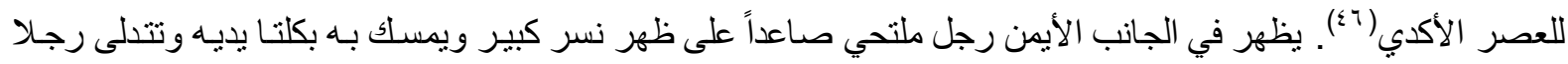

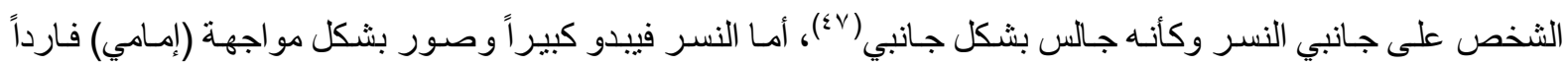

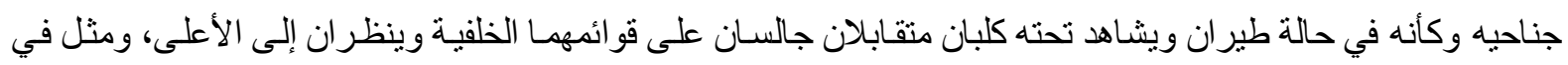
و سط الختم تقريباً رجل ملتحي أخر يرتني تنورة قصيرة ويقف بشكل جانبي ويمسك بيده شيء مـا، وخلفه إنـاء كبير ودلو

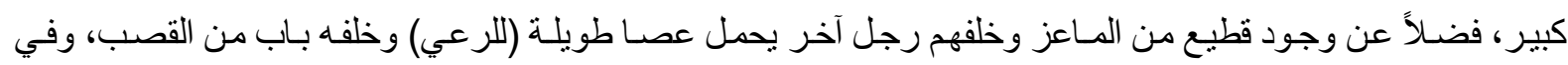

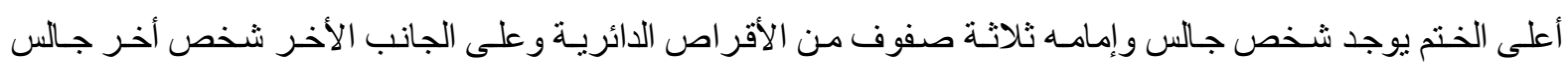

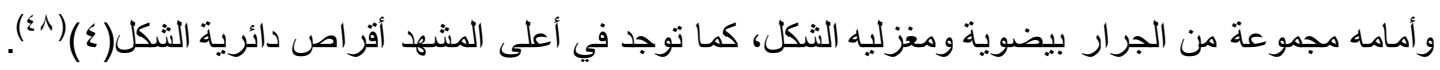
أن وجود الكلاب قد أشير إليهـا بأنها كلاب ايتانـا لأنسه كان راعياً ويستعين بهـا، أمـا الرجلان فهـا من رفاقـهـ الرعاة وهذا إشارة إلى بيئته وأصله حسب مـا يرد في وصفه في جداول الملوك لسومرية (اتيانـا الراعي الذي صعد إلى لى

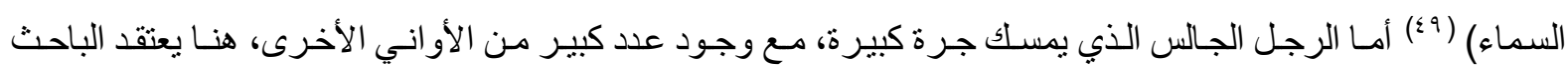

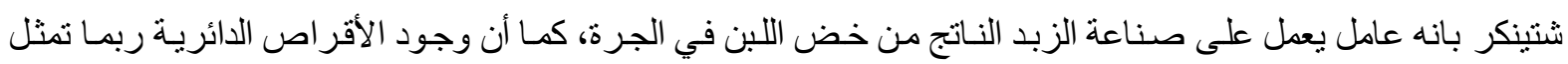
أقر اص الجبن التي تتخمر تحت أشعة الشمس أو ربما تمثل أرغفة الخبز (•). وبالنسبة لقطيع الماشية الذي يتجها نحو الإمـام وكأنه في حالة سير وخلفه سياج من قصب (ربمـا يكون سياج حظيرة) وهو بصورة عامة تفاصيل مكملة للبيئة التي عاش فيها ايتانا ( (0). تعد ملحمة ايتانسا واحدة من الملاحم المهمة والثـهيرة في أدب بـلاد الر افدين بدليل استمرار تداولها لقرون عدة

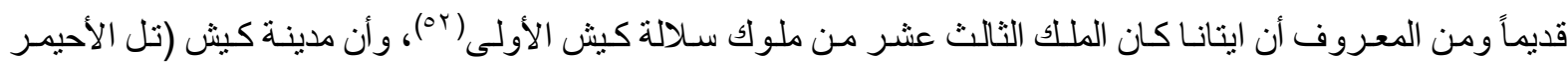

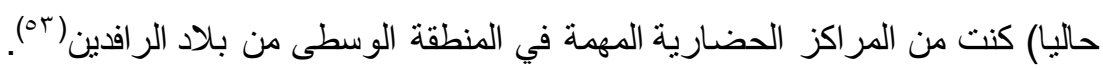

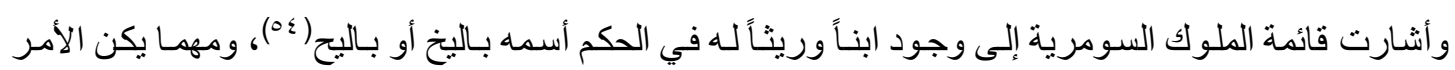

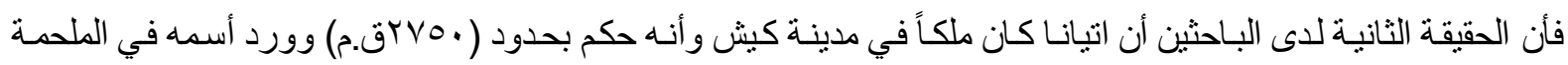

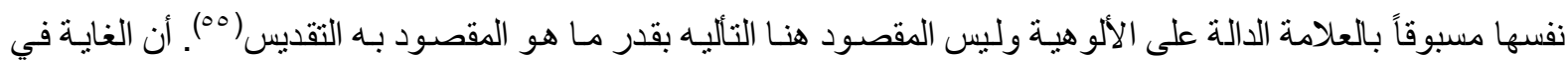




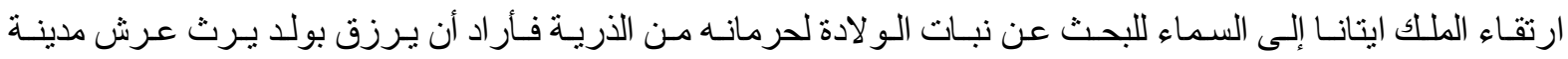

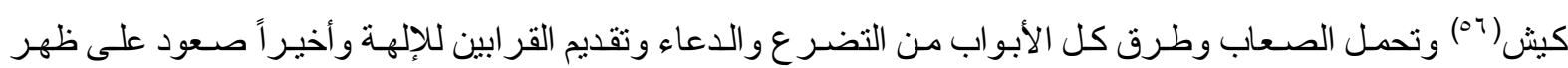
النسر نحو السماء للحصول على مبتخاة.

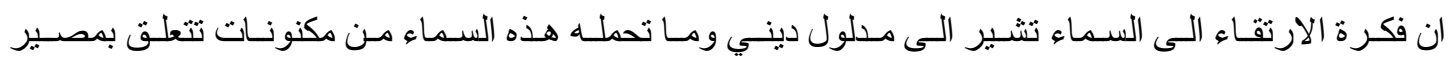

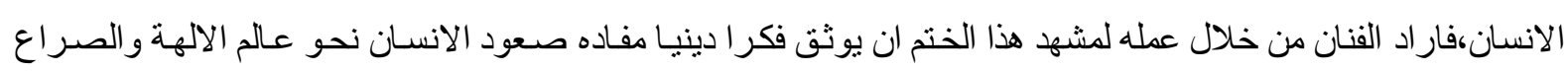
مع القدر و السعي لاسترضاء الالهة.

\section{الكوح بيرني: - 1}

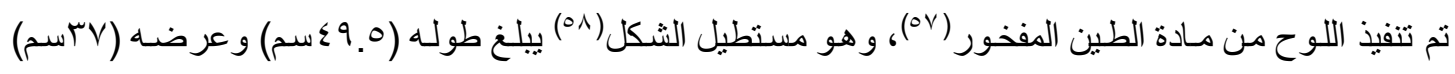

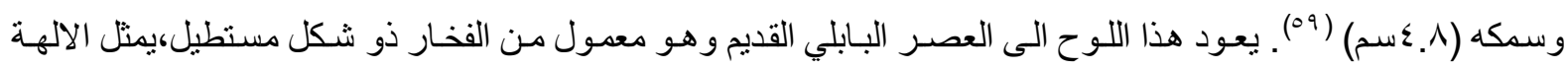

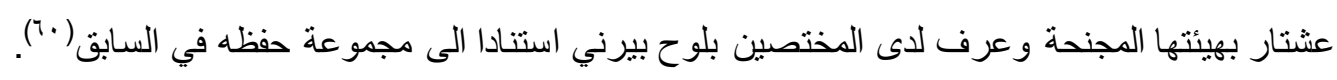
تتوسط الالهة عشتار المشهـ الفني وتهيمن عليه،اذ حرص الفنان في توثيقه لهذا المشهد في ابراز خصوصية للإلهة عشتار تمثلت بالمسـاحة الكبيرة التي شغلتها في هذا المشهـ ونسقها الانثوي وطريقـة تشكيل وتركيب الاجزاء المختلفة لها.

تظهر الالهة عشتار في هذا المشهد وهي معتمرة التاج المقرن رمز الألو هية في بـلاد الرافدين وهي تمسك في

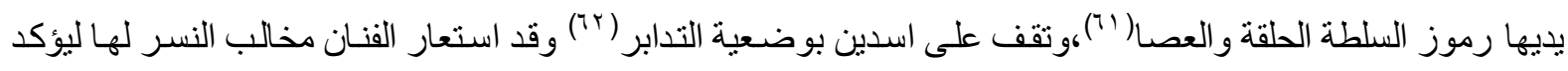

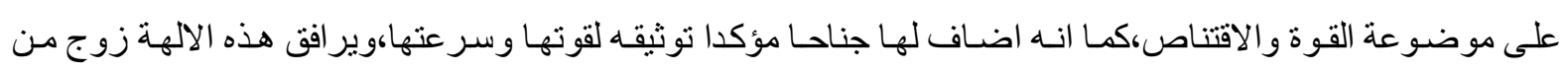
طائر البوم(rآ) وققا على جانبي المشهد بحركة تكاد تكون متقار بـة لحركة الالهة و همـا متجهين الى الامـام بحركة مستقرة

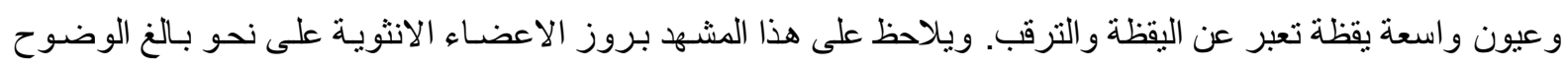

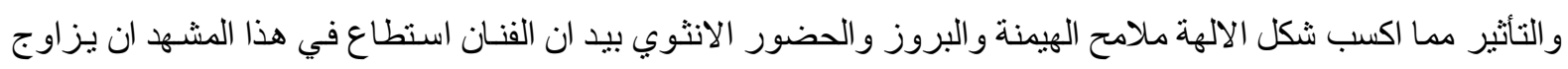

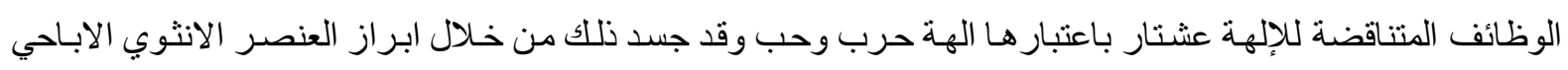

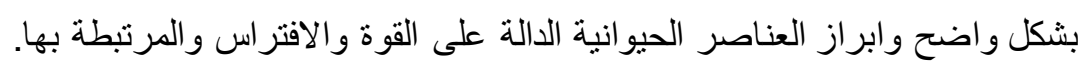

ان توثيق الفكر الديني في هذا المشهـ واضـح جدا وقد عدد الفنان الى ابرازه على خامـة اللوح الذي لعله يعلق

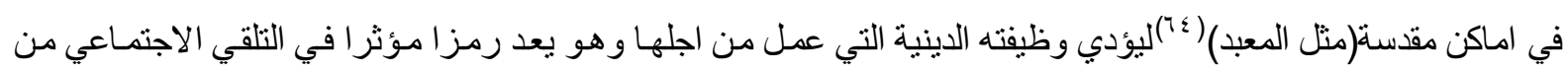
خلال ما يحتويه من افكار دينية. وأن تصوير الأعمال الفنية للإلهة المجنحة العارية بوضعيات مختلفة بدأت منذ العصر السوري الحديثة واستمر

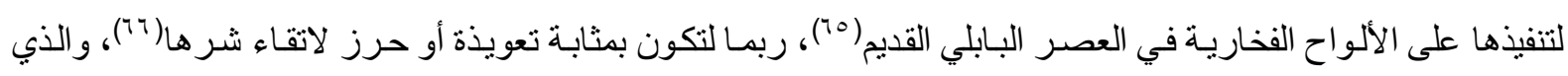

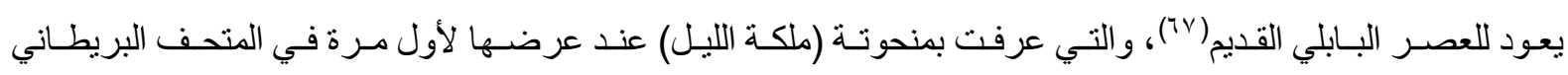

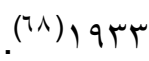

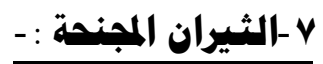

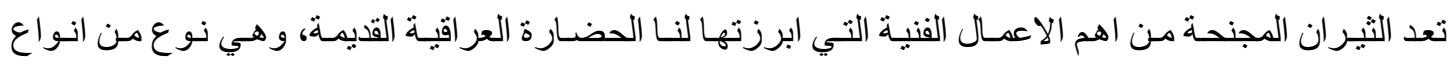
المخلوفات الاسطورية المركبة و التي تسمى (لاماسو) عند الأشوريين، وكانت تقف في مداخل بوابـات المدن و القصسور 
الأشـورية، لأغر اض سـحرية، دينيـة، من أجل حمايتهـا مـن العفاريت و الثـرور القادمـة من الأعداء وكذللك الوقايـة مـن

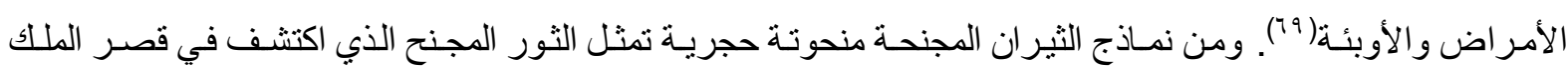
سرجون الأشوري بمدينة (دور شروكين) (خورسباد حالياً) (·ل).

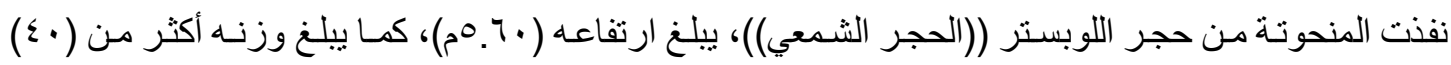

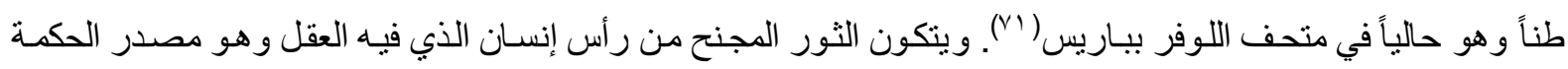

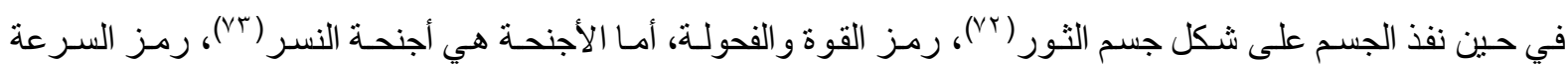
والتألث في السماء والأرض، يتميز النسر ببصيرة ثابتة ورؤية الفريسة من مسـافات بعيدة وسر عة الانقضساض عليها. أمسا

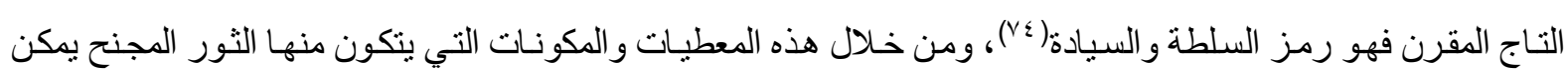
القول بأن الثور المجنح هو مجموعـة قوى فكريـة، وهو يعكس جز ء من ماهيـة الإمبر اطوريـة الأشورية التي كانت مبنية

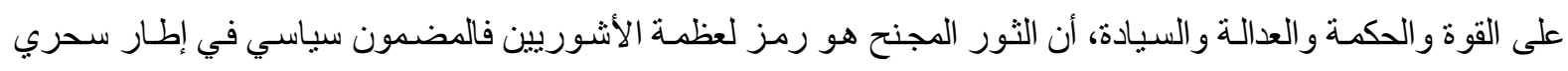

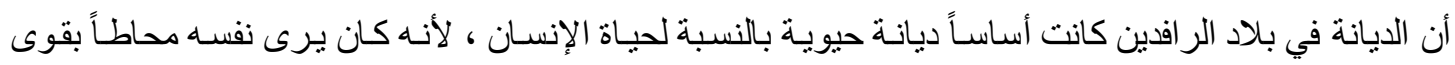

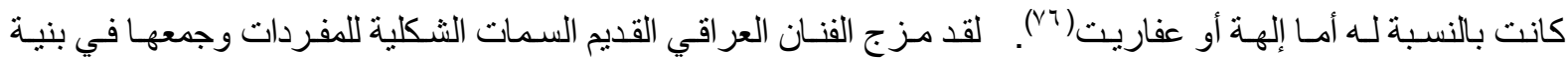

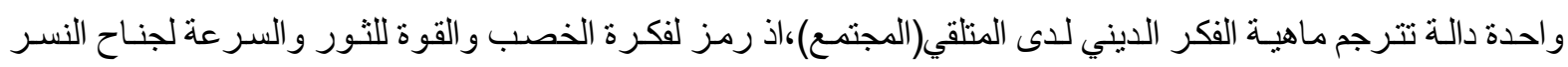

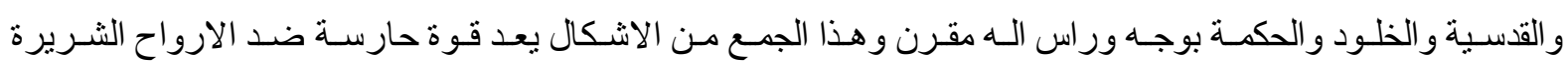
والاعداء(YV) و وصاغ على وفق ذللك جميعه وحدة فنية منكاملة وهي الثور المجنح.

لقد سعى الفنـان الاشـوري الى اقامـة عـالم فنـي تؤلفه عدة رموز فكان للخيـال الاشوري و الدر امـا الدينيـة دورا كبيرا في ابتداع هذه الاشكال.

ان شكل الثور المجنح وحجمه الضخم الهائل والتقنية العالية والدقة في اظهار التفاصيل و التشريح العضلي مـاهو

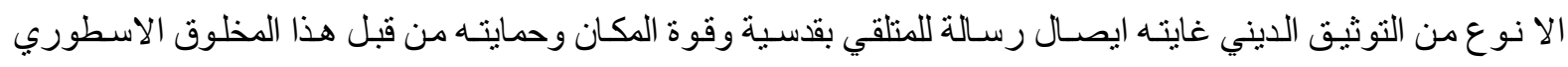
وبنلك وضعت هذه الثثران في مداخل المدن والقصور اذ استخدت بمثابة الملاك الحارس تاكيدا على قدسية المكان. ان اضافة رجل خامسة للثور المجنح يشير الى دلالة السير ،فضـلا عن كونها تحافظ على تحقيق الوازنـة لكتلة

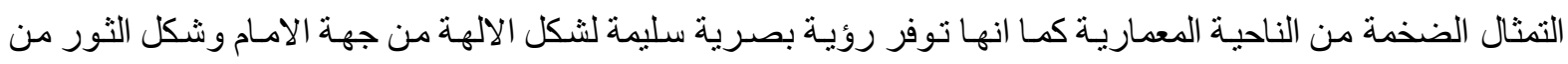
الجانب. وقد ارتبط العمل الفني للثيران المنحة بخصوصية المكان فقد شغلت هذه الثيران بوابات المدن و القصور لتشكل توثيقا مهما مفاده القوة الخارقة التي لا يمكن اقتحامها من اي قوة اخرى. 1-دكة المذبجح (دكة توكلتي تتورتا الأول) : -

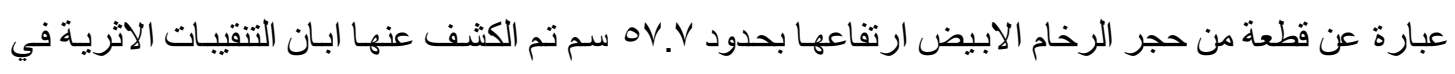

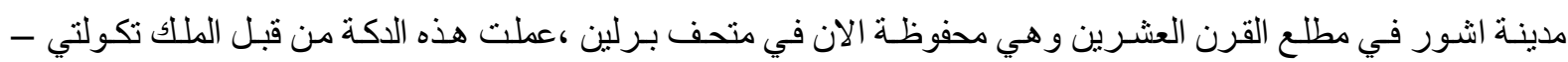

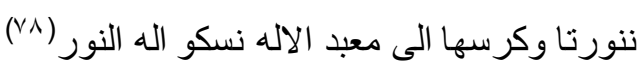


وتعد من أنشهر النمـاذج الفنية المنفذة بالنحت البـارز والتي تعود للعصر الأشوري الوسيط هو مذبح نولكتي

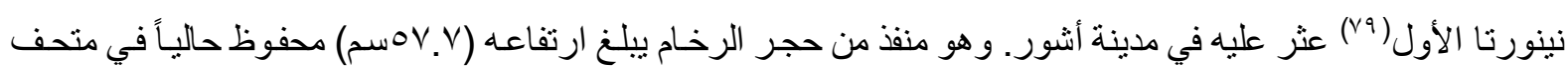
برلين (^)

الموضوع يمثل الملك في فعاليتين مختلفتين، الأولى وهو واقف إمام الإله نوسكو (إله النـار) ( ( )،وهو مسؤول

عن احر اق القر ابين لانهـ يقوم بحسب اعتقادهم بتطهير هـا حبن حرقها، وقد كانت عملية حرق القر ابين شـائعة في مذابح

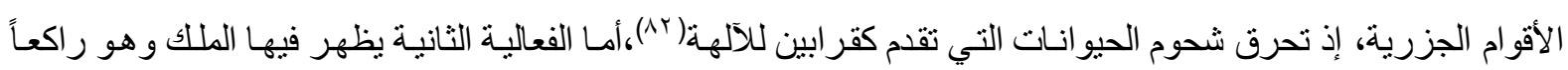
إمام الإله نوسكو (r) الجزئ.

و هناك دكة ذبح اخرى معمولة من حجر الكلس عثر عليها في أشور وهي بارتفاع ؟ + ا م محفوظة في متحف

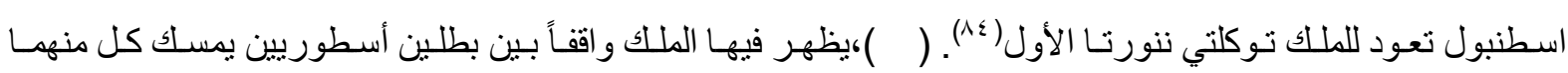

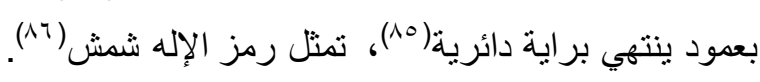

في هذين النحتين البارزين ظهر أسلوب النحت الأشوري المميز بطريقة عمل الشعر بشكل تطغى عليه دوائر

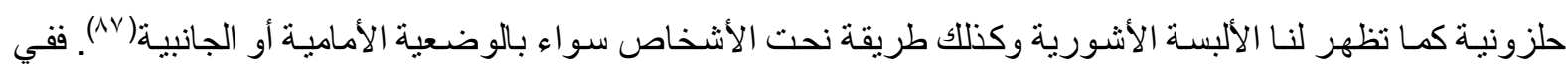

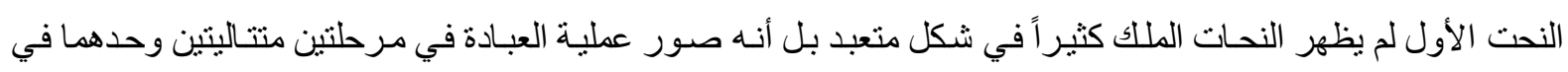
صورة واحدة(1).

يشير المشهد الفني لهذه الدكة توثيقا لفكر ديني يعود الى العهد الاشوري والمشهد برمته تمثيلا للطقوس الدينية امسام المذبح،وقد منلت شخصـية الملك لتقديم القرابين و هي دلالة واضحة الغرض منهـا ايصـال فكرة الدور الديني الذي دئي

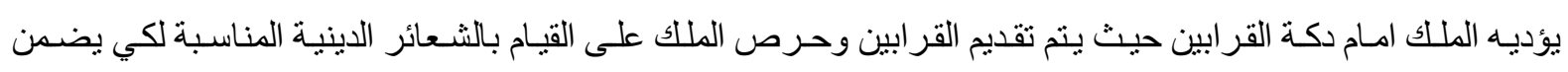

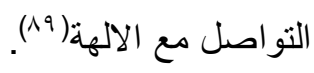

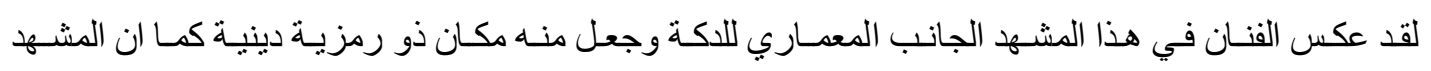
برمته عمل بتكوين معدـاري يتشـابه مع الهيئة الهندسية لشكل المذبح ،امـا في مـا يتعلق بخامـة العمل الفني فقد اراد الفنـان

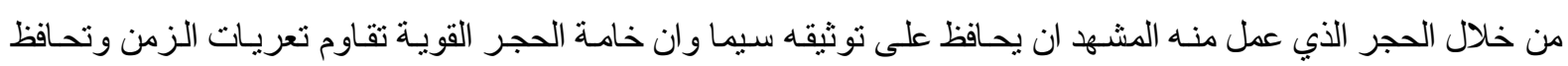
على بيئتها لفترات طويلة.

لقد استطاع الفنـان بهذه الدكـة من تمثيل الواقع العملي واستخدامها بمشـهـ مجسـ بداخلها يحوي على شكل

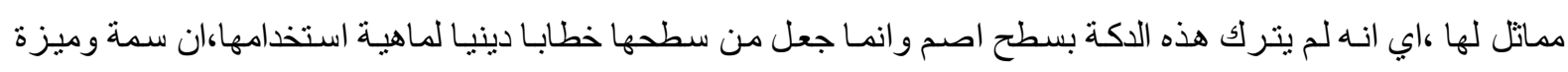

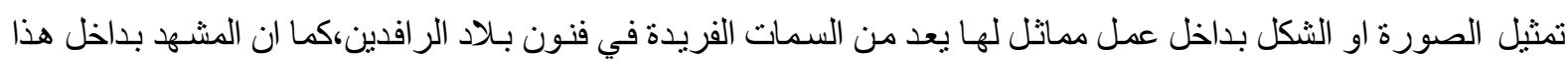

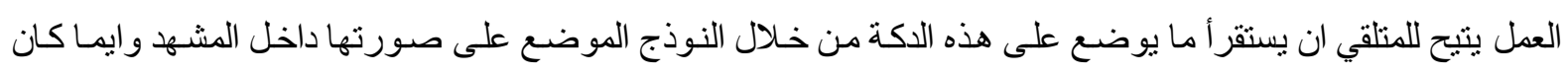

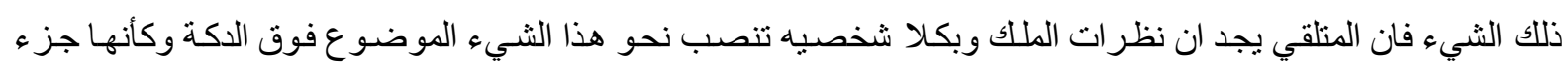

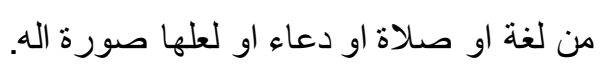

ومن الامور التي يمكن ملاحظتها عن هذا الششه الفني الوضعية التي اتخذها الملك بكلا صورتيه فالاولى وهو

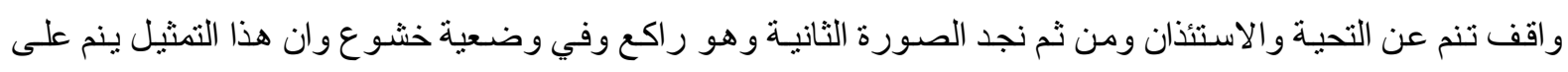
قدرة الفنان من التعبير عن لغة الحدث بواقعه الزماني و والمكاني المتعدد. 
ان الرموز النباتيـة الموجودة في المشـهد الفني(زهـرة البيبـون) والمتماتلـة بتنـاظر جـانبي مـا هو الا انعكـاس الىى رغبة الفنان للإيحاء بالخصوبة والنماء و التي باستمر ارها تستمر عملية تقديم القر ابين وارضـاء الالهة بحسب اعتقادهم لها السلطة العليا في ديمومة الحياة عن طريق الخصب و النماء والمرتبط بديمومة حياتهم.

|اهم|هش

(') احدى المستوطنات الاثرية التي تعود لمدة العصر الحجري الحديث يقع في مدينة فايدة شمال محافظة الموصل، وهو موقع قديم، مساحته

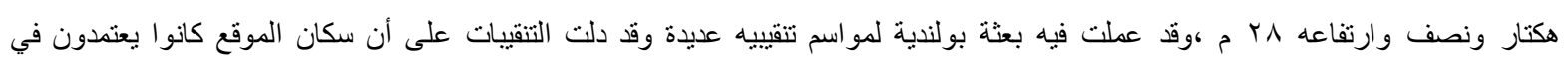

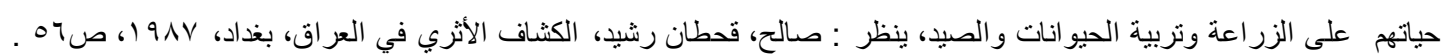

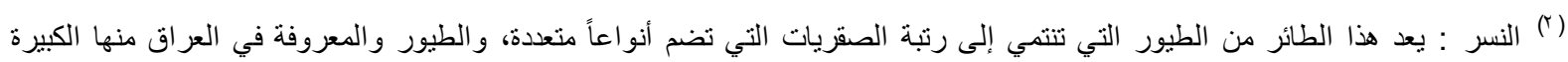

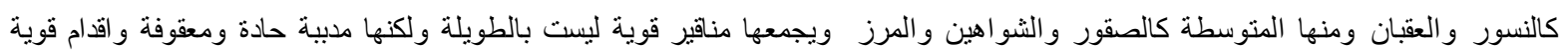
جداً بمخالب طويلة وشديدة التقوس ومدبية الأطر اف تعيش هذه الطيور على الحيو انات الصغيرة من لبائن وزواحف واسماك، ينظر :

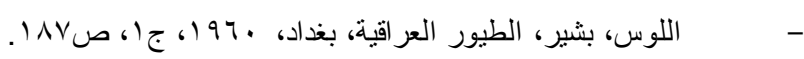

(3) Kozlowski, K, S., NEMRIK1, PRE - PO?TTERY, NEOLITHIG SITEIN IRAQ, Vol.2, House No 1/1A/1B, P.27-29.

(4) Costello, S. K., Using Imagery to interpret Late Neolithic Religion In : Nieuwenburse, O. P,.., et al., Interpreting the Late Neolithic of Upper Mesopotamia, 2013, P.113-124.

(5) Ibid, P.113-124.

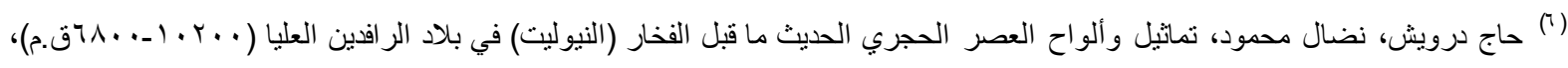

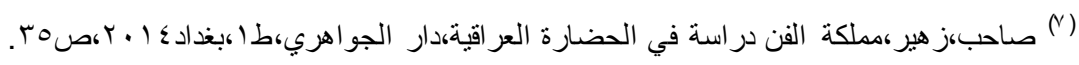

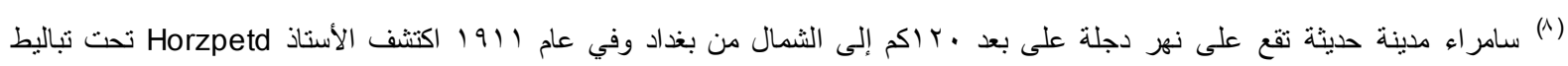
الدور الإسلامية في هذا الموقع عداً كبيراً زانية وكسر فخارية سامر اء في طبعة من الانقاض بسمك هـ ام خالية من المعالم العمارية فوق

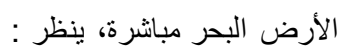

Herzfeld, E., Dic Ausgrabungen Von Samarra, Band. Vorgesch Chtlichen Toppercien Von Samarra, Brelin, 1930, P.1.

(9) Dabbagh. T. , Pottery of early prehistoric Iraq, Unpublished ph. D. I. Thesis, Harvard, University, Cambridge, 1958, P.125.

(10) Braidwood,R.J.,and others, New Chalcolithic Material of samarran Type and its Implication , journal of Near Eastern Studies, Vol. III, No.3, 1944, P.62.

(11) Ippolitioud, F., The Potlery of Tell ES - Samwan, First Season, Estratto de Mesopotamia, Vol. V-VI-, 1970-1971, P.125.

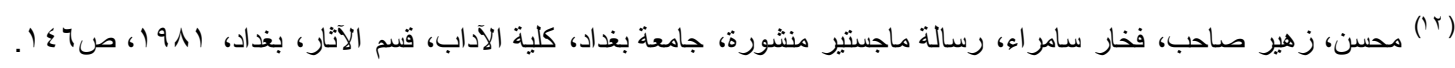

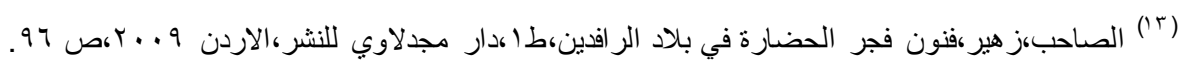

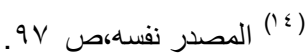

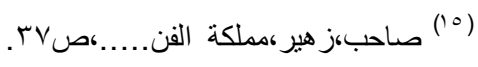

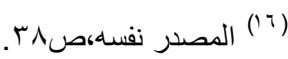

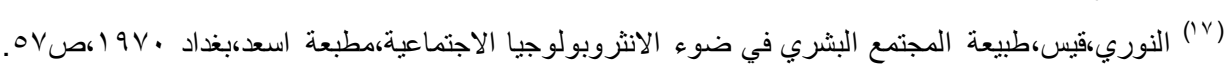




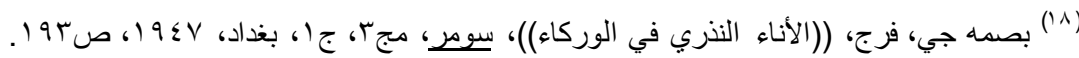

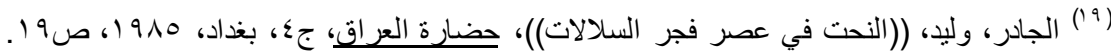

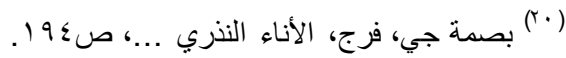

(21) Deimel, A., "Sumerische Zexikon (SL), Roma, (1925-1950), Band, 1, No. 130.

(22) Andrae, W., Die Archaischen ISchtar Temle in Assur, Laipzing, 1935, P.49.

(24) Fakenstein, A., Archaisce Texte aus Uruk, Berlin, 1936, P.59, No. 208.

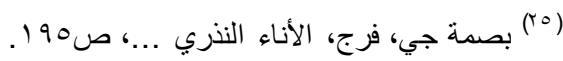

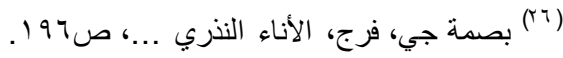

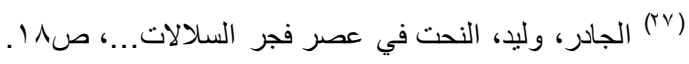

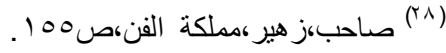

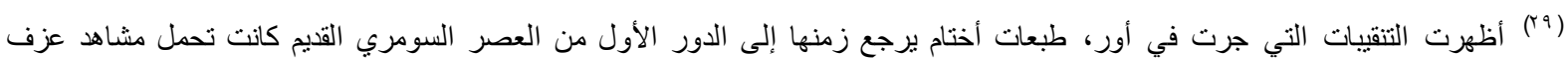

- $\quad$ Legrain, ur Excavation, UE, Vol.3, New York, 1936, PL. 50.

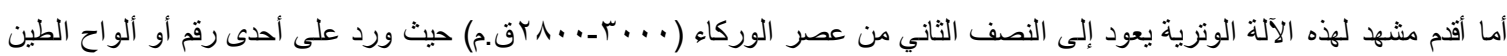

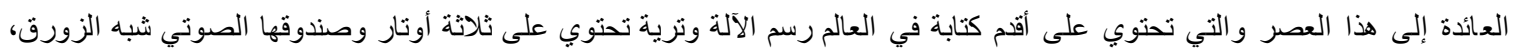
:ينظر :

Fatkenstein, A., Archaische Texte aus uruk, Berlin, 1936, P.69.

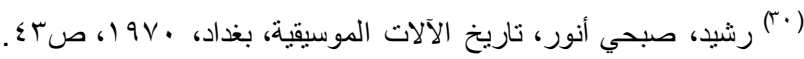

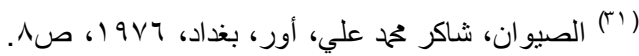

(32) Woolley S.L., ur Excavation II the Royal Cemetery, London, 1934, P.252, PL. 76.

(33) Stauder, W., Die Harfen und Leiern der Sumerer, Frankfurt, 1956, P.47.

(34) Hartmann, H., Die Musik der Sumerischen Kultur, Frankfurt, 1960, P.31.

(35) Stauder W., Die Harfen ....., P.104.

(36) Hartmann, H., Die Musit ....., P.33.

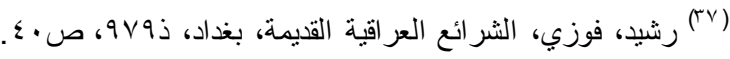

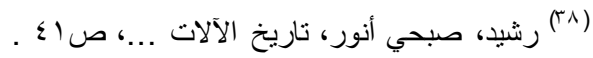

(39) BBSt,No.35,r.2;lambert BWL,204;/raq,30,230:17

(40) CAD,Ș,P. 155:b

(41) TCL,3,385ff;CAD,T,P.417:b

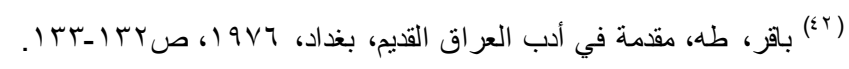

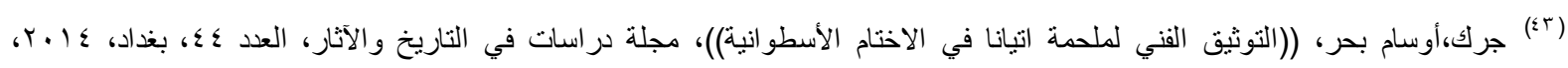

صזrו.

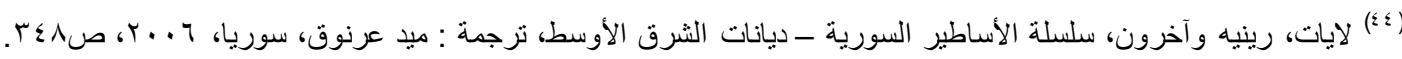

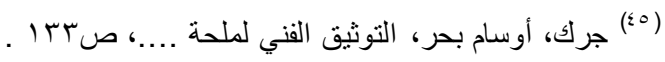




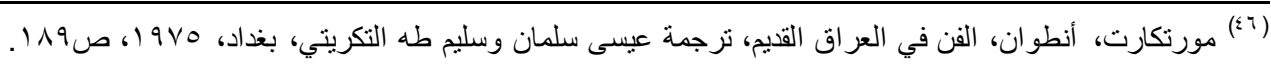

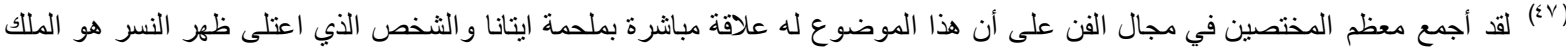

$$
\text { ايتانا الر اعي، للمزيد : ينظر معطر }
$$

- صبحي أنور رشيد، تاريخ الفن في العراق القديم (فن الأختام الأسطو انية)، جا، الكويت، 979 19، ص .

Frankport, H., The Cylinderseals, London, 1939, P.138.

Collon, D., Ancient Near Eastern Art, British, 1995, P.78.

Ward, H., The Seal Cylinder Western Asia, Washington, 1910, P.391.

Woolley, L., Mesopotamia and the Middle East, London, 1963, P.86.

(48) Stenkeller, P., "Early semitic Literature and Third Millennium Seals With Mythological Molifs", Literature and Literary Language at Ebla, Fronsaroli, 1992, P.250.

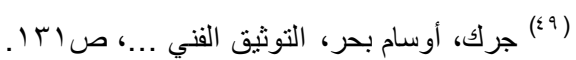

(50) Steintekker, P. "Early Semitic..., P.250.

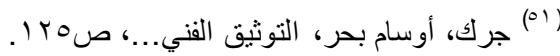

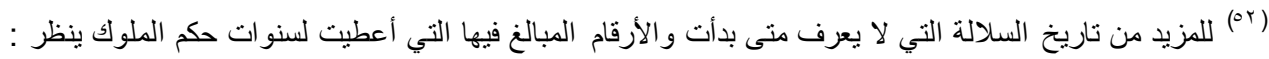

- Jacobsen, Th., The Sumerian King List, Chicago, 1939, P.80-81.

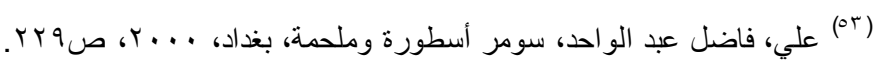

(54) Black, J. and Green, A.Gods, Demons and Symbols of Ancient Mesopotania, British, 1992, P.71.

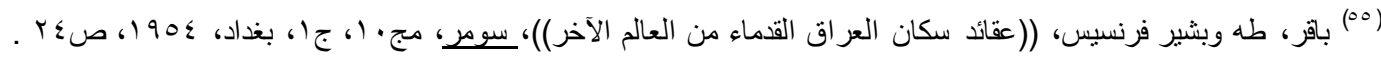

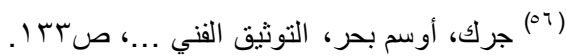

(57) Frankfort, H., The Art and Architecture of the Ancient Orient, London 1958, P.XV, Fig : 56

(م) البصري، إيلاف سعد علي، وظيفة الإبلاغ في الرسوم الجدارية العراقية والمصرية القديمة - دراسة تحليلية مقارنة، بغداد، ^... ؟،

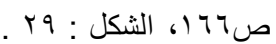

(59) Collon ; D. The Queen of The Night, London, 2005, P.13, Fig : 4.

(60) Julia,A.((Style and replication in ، old Babylonian، terracotta plaques:strategies for entrapping the power of images)),AOAT,band 281,münster(2002)PP.1-30;Al-Khouri,L.S., The nabataean terracotta figurines, unbublished thesis submitted to the university of Mannheim,for the degree of doctor of philosophy mannheim,(2001),P.2.

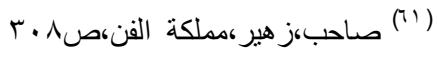

(rr) مهدي، جميل نفل، الجوانب الإبداعية للكائنات المركبة في النحت العراقي القديمة، رسالة ماجسنير غير منشورة، جامعة بغداد، كلية الفنون

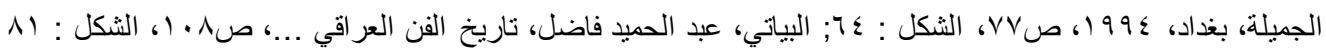
(rT) البومة (OWL) وهي من الطيور الليلية الجارحة التي شاع وجودها في العراق قديماً وحديثاً، وظهرت على الأعمال الفنية في عصر لارسا

$$
\begin{aligned}
& \text { على شكل تميمة. ينظر : عبد اللطيف، سجى مؤيد، الحيوان في أدب العر اق القديم ...، صبس؟. }
\end{aligned}
$$

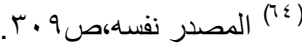

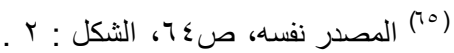

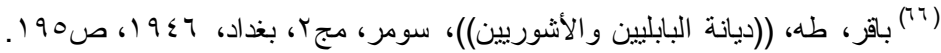


(67) Abusch ; T, and Others, Sumerian Gods and Their Representation's, Groningen, 1997, P.151, fig : 11 .

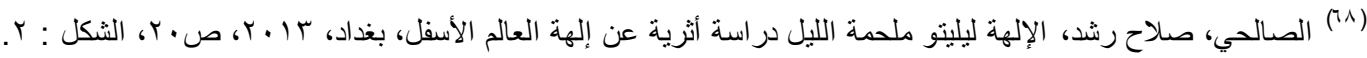

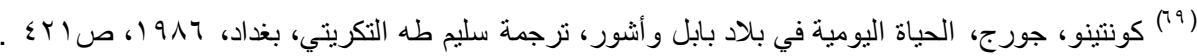

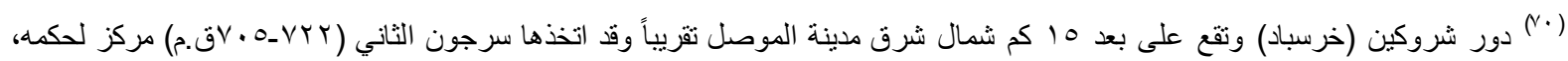

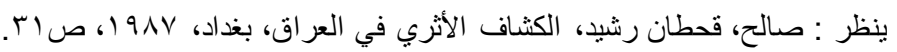

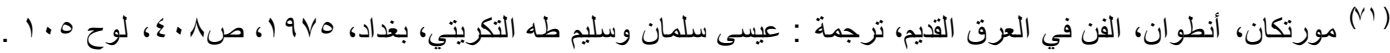

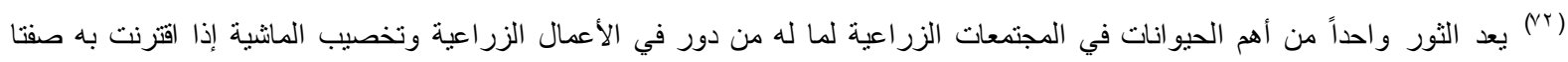
القوة والخصوبة وانعكست أهميته في الفكر و الفن الرافيني، يدخل الثور في تركيب المخلوقات المركبة (الأسطورية) مثل الرجل الثور

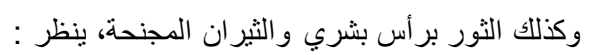

Black \& Green, A., Gods, Demons Symbols of Ancient Mesopotamia, British Museum, 1992, P.51.

(r) يعد النسر من الطيور المعروفة في بلاد الر افدين إلى وقتنا الحاضر ويدخل النسر في تركيب المخلوقات المركبة الأسطورية مثل النسر ذي الني

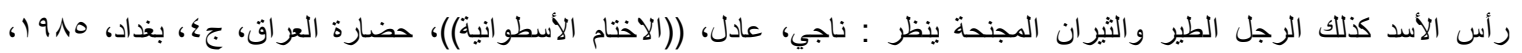

(ء) ظهرت أغطية الر أس المقرنة (التاج المقرن) منذ عصر فجر السلالات واستمر ظهور ها في العصور اللاحقة، ينظر :

Porada, E., Corpus of Ancient Near Eastern Seals, Vol. 1, Text and Plates, Washington, 1948,P.53ff.

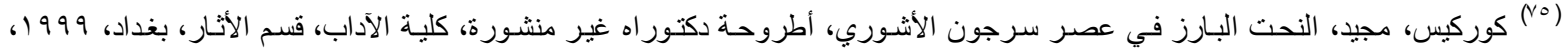

$$
\begin{aligned}
& \text { ص. }
\end{aligned}
$$

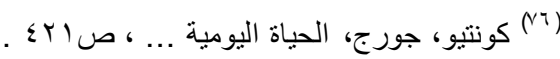

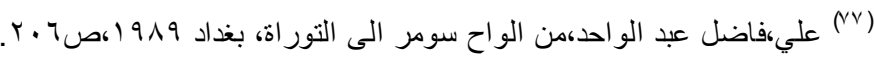

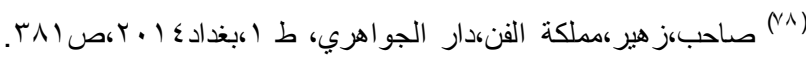

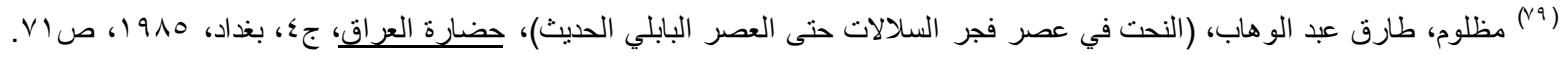

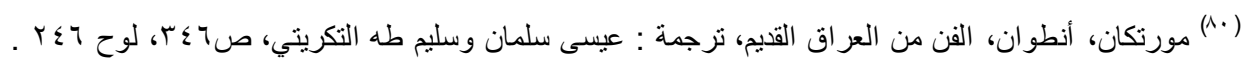

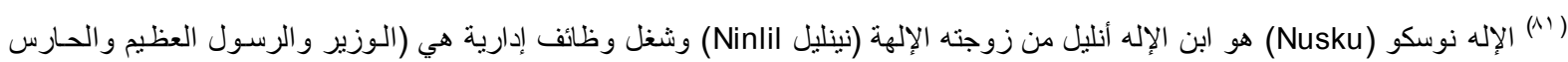

Krebernit, M., "NINLIL" RIA, Vol 19, Berlin \& Leibzig, 1998 - 2007, P.455. : وناظر الخزانة ومدير الأعمال : ينظر

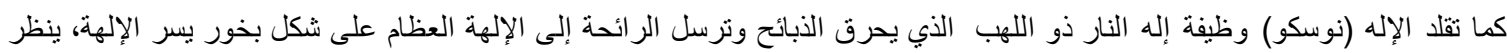

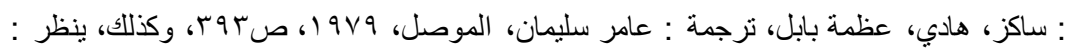

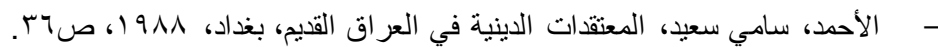

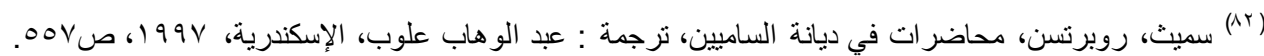

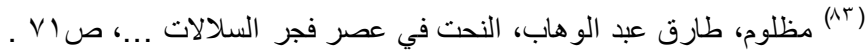

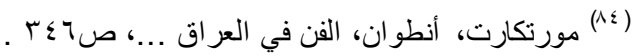

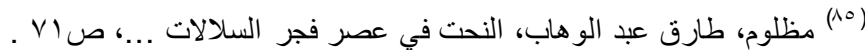

(1) الإله شمش إله العدل ومصدراً للقانون في البلاد، سماه السومريون أونو وسماه البابليون شمش وكان من الإلهة البارز عن بلاد الرائدين

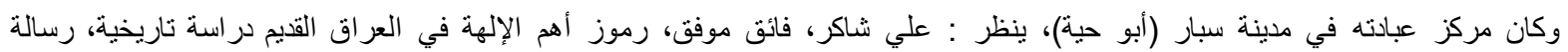

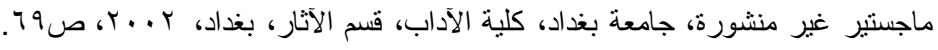

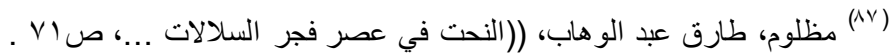

(88) Andrae, W., Die Archaischen Ischtar Temple in Assur, Leipzig, 1975, PL, 30.

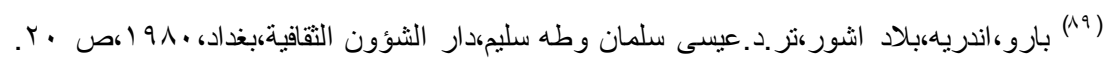

